\title{
Determination of some selected heavy metals in fish and water samples from Hawassa and Ziway Lakes
}

\author{
Kiflom Gebremedhin ${ }^{1}$, Tarekegn Berhanu ${ }^{2}$ \\ ${ }^{1}$ Department of Chemistry, Adigrat University, Adigrat, Tigray, Ethiopia \\ ${ }^{2}$ Quality Monitoring and Testing Laboratory Federal Ministry of Agriculture, Addis Ababa, Ethiopia
}

Email address:

kiflomgmedhin@gmail.com (Kiflom G), tarekegnbr@yahoo.com (Tarekegn B.)

\section{To cite this article:}

Kiflom Gebremedhin, Tarekegn Berhanu. Determination of Some Selected Heavy Metals in Fish and Water Samples from Hawassa and Ziway Lakes. Science Journal of Analytical Chemistry. Vol. 3, No. 1, 2015, pp. 10-16. doi: 10.11648/j.sjac.20150301.13

\begin{abstract}
Samples of Tilapia (Oreochromis niloticus) and African catfish (Clarias gariepinus) were collected from Hawassa and Ziway Lakes during March 1-20 of 2003 E.C. The moisture content of freeze-dried body of the fish collected from six sites ranged between $62.6 \%$ and $86.6 \%(\mathrm{~m} / \mathrm{m})$. An optimal procedure required $12 \mathrm{~mL}$ mixture of $\mathrm{HNO}_{3}, \mathrm{HClO}_{4}, \mathrm{and}_{2} \mathrm{O}_{2}(3: 2: 1$, respectively) to mineralize powdered samples in open refluxed digestion vessels: $0.5 \mathrm{~g}$ of the fish body. The concentrations of 3 toxic elements in the body of the fish determined by flame atomic absorption spectrophotometer varied, respectively, (mg of element $/ \mathrm{kg}$ of fish); $\mathrm{Cd}=0.4-1.85, \mathrm{~Pb}=0.05-0.5$ and $\mathrm{Hg}=0.07-0.096$. The concentration of those three heavy metals in water samples was also determined similarly by FAAS varied, respectively, as ( $\mathrm{mg}$ of element/L of water sample); Cd $=0.06$ $0.66, \mathrm{~Pb}=0.28-0.36$ and $\mathrm{Hg}=0.5-0.74$. Application of the statistical t-test on heavy metal elements data has shown that there was a significant difference between the mean concentrations of $\mathrm{Hg}$ in water samples from the two Lakes. There is no significant difference between fish as well as water sample of the two lakes for the other metals.
\end{abstract}

Keywords: Tilapia Fish, African Cat Fish, Clarias Gariepinus, Oreochromis Niloticus, Toxic Metals, Water Pollution, Lake Hawassa, Lake Ziway

\section{Introduction}

In natural aquatic ecosystems, metals occur in low concentrations, normally at the nanogram to microgram per liter level. In recent times, however, the occurrence of metal contaminants especially the heavy metals in excess of natural loads has become a problem of increasing concern. This situation has arisen as a result of the rapid growth of population, increased urbanization, and expansion of industrial activities, exploration and exploitation of natural resources, extension of irrigation and other modern agricultural practices as well as the lack of environmental regulations [1].

Lakes are more sensitive to pollution inputs because they flush out their contents relatively slowly. Even under natural conditions, Lakes undergo eutrophication, an aging process that slowly fills in the Lake with sediment and organic matter. The eutrophication process alters basic Lake Characteristics such as depth, biological productivity, oxygen levels, and water clarity [2].

In small amounts, trace elements are normal constituents of fresh water organisms but at higher concentrations, they exert ranges of toxic effects that are metabolic, physiologic, behavioral and economical in nature[3]. The toxic actions of trace elements occur due to bioaccumulation and biomagnifications of the elements in tissues of living organisms [4].

The heavy metal concentration in tissues reflects past exposure via water and/or food and it can demonstrate the current situation of the animals before toxicity affects the ecological balance of populations in the aquatic environment [5]. Since water is the basis for all organisms and ecosystems, protection of aquatic resources is essential in protecting the entire ecosystem.

Ethiopian Rift Valley Lakes which comprises of seven principal Lakes is an important area for commercial fisheries. The Lakes are also used for recreation, irrigation and industrial purposes [6]. Despite the growing influences from natural and anthropogenic origins, there exists a general belief that presumes absence of permanent alteration or contamination of these Lakes. However, rivers that flow into some of these Lakes are heavily loaded with contaminants of natural and anthropogenic origin such as discharges from 
factories and domestic sources [6].

Taking into consideration that these lakes are closed ecosystem, and as a result of extensive evaporation of water, the accumulation of chemical pollutants (salts, heavy metals, pesticides and other pollutants) is expected to increase annually in all their components (e.g. water, sediment and fish) and to change their quality and affect their aquatic life [7].

This research focuses on the studying of distribution of Mercury, Lead and Cadmium in water and fish tissues of Lakes Hawassa and Ziway.

\subsection{Objective}

\subsubsection{General Objectives of the Study}

The aim of this study is to determine some selected heavy metal concentrations in both water and fish species from Hawassa and Ziway Lakes and compare with acceptable levels.

\subsubsection{Specific Objectives}

- To determine $\mathrm{Cd}, \mathrm{Hg}$ and $\mathrm{Pb}$ concentrations in water samples from the two Lakes.

- To determine the $\mathrm{Cd}, \mathrm{Hg}$ and $\mathrm{Pb}$ concentrations in the fish species from the two Lakes.
- To compare the degree of contamination of water in these two Lakes.

- To compare the degree of contamination of the typical fish between these two Lakes.

- To compare the levels of heavy metals in the two Lakes with the internationally accepted levels.

\section{Methodology}

\subsection{Instrumentation and Chemicals}

\subsubsection{Instrumentation}

The instrument used was fully automated PC-controlled true double-beam atomic absorption spectrometer with FS (fast sequential operation) for fast multi element air acetylene flame AA determinations. Its features have 4 lamp positions and automatic lamp selection, operated with specter AA Base and pro-software versions with each three hollow cathode lamp namely Cadmium, Mercury and lead were used throughout the experiment. Therefore, the general settings and operational parameters of atomic absorption spectroscopy used in this study are listed as follows.

Table 1. Operating parameters of AAS instrument

\begin{tabular}{|c|c|c|c|c|c|c|}
\hline \multirow{2}{*}{$\begin{array}{l}\text { Heavy } \\
\text { Metals }\end{array}$} & \multicolumn{6}{|c|}{ Operating parameters and setting } \\
\hline & Lamp current & Wave length & Slit width & Flow rate of combustion gas (air) & Flame type & $\begin{array}{l}\text { Flow rate of combustion gas } \\
\text { (acetylene) }\end{array}$ \\
\hline $\mathrm{Hg}$ & $4 \mathrm{~mA}$ & $253.7 \mathrm{~nm}$ & $0.5 \mathrm{~nm}$ & $13.50 \mathrm{mLmin}^{-1}$ & oxidizing & $2.0 \mathrm{mLmin}^{-1}$ \\
\hline $\mathrm{Cd}$ & $4 \mathrm{~mA}$ & $228.8 \mathrm{~nm}$ & $0.2 \mathrm{~nm}$ & $13.50 \mathrm{mLmin}^{-1}$ & Reducing & $2.0 \mathrm{mLmin}^{-1}$ \\
\hline $\mathrm{Pb}$ & $4 \mathrm{~mA}$ & $230.1 \mathrm{~nm}$ & $0.4 \mathrm{~nm}$ & $13.50 \mathrm{mLmin}^{-1}$ & oxidizing & $2.0 \mathrm{mLmin}^{-1}$ \\
\hline
\end{tabular}

Table 2. List of all chemicals and standards used

\begin{tabular}{ll}
\hline Chemicals & Apparatus \\
\hline Ethanol, Perchloric acid $(70 \%$ spectrosol) & Dissecting, kit, Hooks, Rope \\
Formaldehyde, Hydrogen peroxide $(35 \%$ Riedel- de Haen), Nitric acid (70\% spectrosol) & Refluxer, Boiler, Ice box, Knives \\
&
\end{tabular}

\subsubsection{Study Area}

This study focuses on two Ethiopian Riftvally Lakes that found on the main road as we go from Addis Ababa to Hawassa city. These Lakes are Lake Hawassa which is found in Hawassa city, Lake Ziway which is found in Ziway town. Their description is provided as follows.

\section{Lake Ziway}

Lake Ziway is found in the Great East African Rift Valley and in the Northern Rift valley Lakes of the Country. It is located between $7^{\circ} 51^{\prime} \mathrm{N}$ to $8^{\circ} 7^{\prime} \mathrm{N}$ and $38^{\circ} 43^{\prime} \mathrm{E}$ to $38^{\circ} 57^{\prime} \mathrm{E}$. It has an open water area of $434 \mathrm{~km}^{2}$, shoreline length of $137 \mathrm{~km}$ and average depth of $4 \mathrm{~m}$. The Lake has two tributaries and has one outflow in the south [7]. It is extended up to Meki town as we go from Ziway to Addis Ababa.

The fishing ground is used by co-operative members and private fishers where the latter occasional fishers are motivated and supported by occasional fish traders. Cooperatives are not liable for any payments to the government for use of the fish stocks and the private fishers are accused of being illegal, unorganized and not being liable for any governmental obligations.

\section{Lake Hawassa}

Lake Hawassa $\left(6^{0} 33^{\prime}-7^{0} 33^{\prime} \mathrm{N}\right.$ and $\left.38^{0} 22^{\prime}-38^{0} 29^{\prime} \mathrm{E}\right)$ is the smallest lake in the main Ethiopian Rift Valley, which receives surface inflow mainly containing factories and domestic waste through Tikur Wuha River (Gebremeriam, 2001). It is located in a topographically closed basin and has no surface outflow. Its local name so called "yefikir hayk" and it is very useful mostly for recreation together with production of fish species. Peoples they found near that Lake said that there are five types of fish species in that Lake. However, in order to compare with the fish types found in Ziway Lake only two of them were collected for analysis. Those collected fish types are Tilapia (Oreochromis neloticus) its local name called "koroso" and African cat fish (Clarias gariepinus) were selected because of most abundant species in both of these Lakes.

\subsubsection{Sample and Sampling}

\subsubsection{Fish Sampling and Drying}

Fish samples were collected from six stations of each two lakes (Deset, Minch, and Tikur Wuha in Lake Hawassa; Kofe, 
Koli, and Shalo in Lake Ziway using plastic nets. The freshly collected fishes (15-30 cm long) were two types namely tilapia (Oreochromis neloticus) and African cat fish (Clarias gariepinus) washed with the Lake water, distilled water, $\mathrm{HNO}_{3}$ containing distilled water and was placed on plastic sheet. The collected fish were dissected its edible parts using plastic knife and quickly wrap with plastic bags. The bags were frozen in icebox until brought to laboratory. The samples were then frozen at $-20{ }^{\circ} \mathrm{C}$ in deep-freezer unit until freeze-dried (FRREZE DRY-3, LABCONCO, USA). The moisture contents of the samples were determined by monitoring the loss in mass of wet specimen during the freeze-drying process until constant dry mass was obtained. The freeze-dried samples of tissue from the two Lakes were mechanically crushed with glass rod and homogenized on their own two parts in freeze-drying flask. The dry specimen of tissue was then powdered in a blending machine (Moulinex, France) and there are two specimens each from the two Lakes.

\subsubsection{Collection of Water Samples}

Similarly, water sample were collected from six stations of each three Lakes (Deset, Minch, and Tikur Wuha in Lake Hawassa, Kofe, Koli and Shala from Lake Ziway. This was performed by the distance of $50 \mathrm{~cm}$ in order to get representative sample and $50 \mathrm{~cm}$ depth was freshly collected in order to excluded the dust materials as well as oily liquids suspended above the Lake to the container. Finally, the freshly collected water sample was mixed together and was taken the composite sample for digestion process for each Lake.

\subsubsection{Preparation of Stock Standard Solution for Calibration}

Calibration curves were prepared for each of the metals by running a range of concentration of freshly prepared standard solution in their respective linear ranges. For the linear dynamic range, the calibration samples were prepared using appropriate dilution of the stock cadmium, mercury and lead (stock solutions of $1000 \mathrm{ppm}$ for each metals) solutions in a solvent. For $\mathrm{Cd}$ serial concentration was prepared as follow: $0.01,0.10,0.20$ and $0.3 \mathrm{~mL}$ from $10 \mathrm{ppm}$ intermediate standard stock solutions in order to obtain the corresponding absorbance. Similarly, for $\mathrm{Pb}$ and $\mathrm{Hg}$ were prepared as follow: $0.05,0.10,0.20$, and 0.30 and also $0.5,1.0,2.0$ and 4.0 respectively from $10 \mathrm{ml}$ of intermediate concentration.

\subsubsection{Method Validation}

In the analysis of heavy metals in tilapia and cat fish samples, reference materials, blanks and spikes were included for the analytical method validation. Blank analysis was carried in order to check interference from instruments. Individual reference standards of heavy metals $(\mathrm{Cd}, \mathrm{Pb}$, and $\mathrm{Hg}$ ) were used to identify and quantify the level of samples. Arithmetic mean and standard deviation were calculated from positive quantifiable samples only. The instrument detection limit, IDL was determined via statistical calculations using calibration plots established at concentration levels close to the expected method detection limit (MDL). Accordingly, the IDL is defined as $3(\mathrm{Sy} / \mathrm{x}) / \mathrm{a}$ and the LOQ as $10(\mathrm{Sy} / \mathrm{x}) / \mathrm{a}$, where $\mathrm{Sy} / \mathrm{x}$ represents the residual standard deviation and $a$ is the slope of the calibration plot.

\subsection{Digestion Procedures of Fish and Water Sample}

\subsubsection{Digestion Procedure of Fish Sample}

The collected fish sample was dried in an oven at $105^{\circ} \mathrm{C}$ and the moisture content of each of the fish species was calculated. After that, it was transferred to the furnace oven and completely dried at $550{ }^{\circ} \mathrm{C}$. The dried sample was then powdered using mortar and pistil (Moulinex, France) and made ready for digestion process. $0.5 \mathrm{~g}$ of the powdered fish sample was placed in a $100 \mathrm{~mL}$ round bottom flask with ground glass joint and mineralized under reflux using a mixture of $6.0 \mathrm{~mL}$ nitric acid (70\%, Spectrosol), $2.0 \mathrm{~mL}$ perchloric acid (70\%, Spectrosol) and $4.0 \mathrm{~mL}$ hydrogen peroxide (35\%, Riedel-de Haen). The digestion procedure took 5:30 hours to obtain clear solution. A triplicate digestion was done for each sample and finally transferred to $25 \mathrm{~mL}$ volumetric flask and diluted to the final volume.

\subsubsection{Digestion of Water Samples}

Digestion of water took place after composite samples were prepared from the two Lakes. First of all a mark in about $20 \mathrm{~mL}$ of the beaker was made using marker. Triplicate water samples of each of the two Lakes were prepared and $100 \mathrm{~mL}$ of each of them was measured using volumetric cylinder and was added to the previously marked beaker. Then it was boiled until the solution reached up to the mark and finally $2 \mathrm{~mL}$ of nitric acid was added to get clear solution.

\subsection{Analysis of Heavy Metal Elements in Standard and Sample Solutions}

Trace elements like $\mathrm{Cd}, \mathrm{Hg}$ and $\mathrm{Pb}$ were analyzed from the diluted digests of fish and water samples using flame atomic absorption spectrophotometer Varian specter AA photometry and Varian AA 240 FS fast sequential atomic absorption photometry using aqueous calibration standards prepared from stock standard solutions of the respective elements.

\section{Results and Discussion}

\subsection{Results}

\subsubsection{Calibration and Detection Limit}

Calibration curves were plotted and validated with their corresponding $\mathrm{R}^{2}$ values for the determination of each metal. The values of $\mathrm{R}^{2}$ of the curves were 0.99981, 0.99985, 0.99949 , for $\mathrm{Hg}, \mathrm{Pb}$, and $\mathrm{Cd}$, respectively. The respective calibration curves are given in Fig. 4 below. 
Table 3. Concentration of standard solutions and linearity of calibration for the determination of heavy metals

\begin{tabular}{|c|c|c|c|}
\hline Heavy metal & Intermediate standards (mg/Kg) & Series of standards $(\mathrm{mg} / \mathrm{L})$ & Linearity $\left(r^{2}\right)$ \\
\hline $\mathrm{Cd}$ & 10 & $0.01,0.10,0.20,0.30$ & 0.99992 \\
\hline $\mathrm{Pd}$ & 10 & $0.05,0.10,0.20,0.30$ & 0.99985 \\
\hline $\mathrm{Hg}$ & 10 & $0.05,1.0,2.0,4.0$ & 0.99949 \\
\hline
\end{tabular}

\subsubsection{Moisture Content}

The moisture content of fish tissues was determined by monitoring the weight loss of the wet tissues until constant dry mass was obtained in freeze-drying unit. The moisture content was then calculated as percent loss of the mass.

$$
\text { Percent loss mass }=\frac{\text { wet mass of the fish }- \text { dry mass }}{\text { Dry mass }} \times 100 \%
$$

The mass loss calculated varied from $62.6-78.4 \%$ in tilapia of Hawassa sample (Oreochromis neloticus), $78.7-85.3 \%$ in Africa catfish (Clarias gariepinus) of Hawassa sample, 80.5$83.6 \%$ in tilapia (Oreochromis neloticus) of Ziway fish sample and 76.0-86.8\% in Africa catfish (Clarias gariepinus) of Ziway fish sample. The moisture contents determined in this study are in good agreement with previous reports [8] of our laboratory, which was in the range of $79.3-82.5 \%$ in edible tissue (muscle) reported the average moisture content of $82 \%$ for different fish species.

Validation of the Analytical Method of the digestion processes

The instrumental detection limit (IDL), limit of quantification (LOQ) and method of detection limit (MDL) result calculated in this study are shown Table 5 .
Table 4. Method Detection limit, instrument Detection and Quantification limits

\begin{tabular}{llll}
\hline Element & IDL & LOQ & MDL \\
\hline $\mathrm{Cd}$ & 0.01 & 0.0333 & 0.014 \\
$\mathrm{~Pb}$ & 0.04 & 0.0133 & 0.23 \\
$\mathrm{Hg}$ & 0.05 & 0.0166 & 0.056 \\
\hline
\end{tabular}

\subsubsection{Percent Recovery}

Method recovery determination was usually helpful in the absence of certified reference material to evaluate the accuracy of the method applied for the analyte determination. The recovery was calculated from the analysis of spiked fish samples. This was performed by carefully spiking the standard solution prepared, which was $20-50 \%$ of the sample concentration, in to all samples and checked to what extent the standard added could be recovered after determination through sample preparation. Spike recoveries were calculated according to the following formula;

$$
\text { Percent recovery }=\frac{\text { spiked result }- \text { unspiked result }}{\text { added amount }} \times 100 \%
$$

Recovery was assessed using spiked samples at two concentration levels. The results of the recovery study for fish and water samples are summarized in Table 7 and 8 , respectively.

Table 5. Percentage recovery of detected heavy metals in the body of Oreochromis niloticus and Clarias gariepinus

\begin{tabular}{llllll}
\hline $\begin{array}{l}\text { Heavy } \\
\text { metals }\end{array}$ & unspiked concentration $(\mathbf{m g} / \mathbf{k g})$ & Sample Name & Added amount(mg/l) & Spiked concentration (mg/kg) & \% recovery \\
\hline $\mathrm{Cd}$ & 1.02 & Oreochromis niloticus & 0.2 & 1.21 & $97.3 \pm 1.02$ \\
& 1.09 & Clarias gariepinus & 0.21 & 1.28 & $94.06 \pm 2.74$ \\
$\mathrm{~Pb}$ & 2.4 & Oreochromis niloticus & 0.5 & 2.86 & $92.4 \pm 1.4$ \\
& 3.5 & Clarias gariepinus & 0.7 & 4.13 & $91.09 \pm 1.3$ \\
$\mathrm{Hg}$ & 80.06 & Oreochromis neloticus & 1.6 & 81.69 & $102.1 \pm 2.41$ \\
& 90.3 & Clarias gariepinus & 1.8 & 92.17 & $104 \pm 1.37$ \\
\hline
\end{tabular}

Table 6. Percentage recovery of detected heavy metals in water sample

\begin{tabular}{llllll}
\hline Heavy metals & unspiked concentration & sample & Added amount(mg/l) & Spiked concentration (mg/l) & \% recovery \\
\hline $\mathrm{Cd}$ & 0.06 & Water & 0.01 & 0.069 & $94.06 \pm 2.74$ \\
$\mathrm{Pd}$ & Water & 0.06 & 0.37 & $91.09 \pm 1.3$ \\
$\mathrm{Hg}$ & 0.32 & water & 0.9 & 5.476 & $104 \pm 1.37$ \\
\hline
\end{tabular}

Table 7. Distribution of trace elements ( $m g$ elements/kg dry mass) in Tilapia and cat fish from lakes Hawassa and Ziway (mean \pm s.d for $n=3$ )

\begin{tabular}{lllllll}
\hline \multirow{2}{*}{ No } & \multirow{2}{*}{ Element } & Site & Hc & Zt & Zc & detection limit \\
\cline { 3 - 7 } & Ht & $1.85 \pm 0.04$ & $1.45 \pm 0.05$ & $0.40 \pm 0.05$ & $0.46 \pm 0.05$ & 0.014 \\
2 & $\mathrm{Cd}$ & $0.55 \pm 0.002$ & $3.58 \pm 0.41$ & $1.859 \pm 0.06$ & $3.85 \pm 0.04$ & 0.23 \\
3 & $\mathrm{Pd}$ & $0.078 \pm 0.005$ & $0.07 \pm 0.85$ & $0.088 \pm 0.0011$ & $0.091 \pm 0.001$ & 0.056 \\
\hline
\end{tabular}

\subsection{Discussion}

Optimum method was selected for sample digestion from the tested procedures with preconditions producing clear and colorless solutions with minimum reagent volume, less time and digestion temperature. The method fulfilling such conditions considered to be optimum [9]. The efficiency of methods used for sample preparation was evaluated with 
spiked recoveries and the detected heavy metals indicated a recovery above $90 \%$ with relative standard deviations below $10 \%$ showing that the method used was efficient.

\subsubsection{Distribution of Heavy Metals in Fish Species of the Two Lakes}

All the three toxic elements evaluated in this study were above detection limits in the edible part of the fish species and the method detection limits of each element (Table 9) were calculated as $M D L=S\left(t_{n-1}\right)$.

As can be observed from Figure 2, the distribution of heavy metals varied as follows: Cd concentration varies in the order: $\mathrm{Ht}>\mathrm{Hc}>\mathrm{Zc}>\mathrm{Zt}$, while $\mathrm{Pb}$ concentration was accumulated in the order $\mathrm{Zc}>\mathrm{Hc}>\mathrm{Zt}>\mathrm{Ht}$ while the concentration of $\mathrm{Hg}$ was in the order of $\mathrm{ZC}>\mathrm{Zt}>\mathrm{Hc}>\mathrm{Ht}$.

Cadmium (Cd)

Concentration of cadmium in fish samples at the present study, as shown in table 7 , was varied from $0.4-1.85 \mathrm{mg} / \mathrm{Kg}$ in the two fish species of the two Lakes. The mean cadmium concentration of the two fish species in Hawassa Lake namely Tilapia (Oreochromis nilotica) and catfish (Clarias gariepinus) were significantly different at $95 \%(\mathrm{p}=0.05)$ confidence level, but, the mean Cd concentration in the two fish species of Ziway were not significantly different based on the findings of students t-test calculated. Cd concentration of tilapia fish species in Hawassa Lake was highest in concentration than the rest of fish species while lowest concentration was obtained from tilapia fish species of Ziway Lake. Generally, the distribution of $\mathrm{Cd}$ in the two fish species from both Lakes was in the order: $\mathrm{Ht}>\mathrm{Hc}>\mathrm{Zc}>\mathrm{Zt}$.

Although there are inter-species as well as locality differences, the concentrations of $\mathrm{Cd}$ in the present study were low when compared to literature reports from different areas [10] for example, determined the concentration of $\mathrm{Cd}$ as high as $8.1 \mathrm{mg} / \mathrm{kg}$ dry mass, which was far above the maximum concentration determined in the present study.

\section{Lead $(\mathrm{Pb})$}

Lead is one of the metals of particular interest in this investigation and its concentration ranged from $0.55-3.85$ $\mathrm{mg} / \mathrm{Kg}$. As can be seen from table 7 above, the concentration distribution of lead found in the two fish species of the two Lakes was in the order: $\mathrm{Zc}>\mathrm{Hc}>\mathrm{Zt}>\mathrm{Ht}$. The mean lead $(\mathrm{Pb})$ concentration in each species of the two Lakes were not significantly different at $95 \%(p=0.05)$ confidence level. Out of the two species in the present study, the concentration of lead in the cat fish species of Ziway Lake was obtained to be highest $(3.85 \mathrm{mg} / \mathrm{Kg})$ whereas, the concentration of Lead in Hawassa tilapia fish species was the lowest $(0.55 \mathrm{mg} / \mathrm{Kg})$. The concentrations of $\mathrm{Pb}$ in the present study were low when compared to literature reports from different areas [10].

\section{Mercury $(\mathrm{Hg})$}

The distribution order of concentration in the two species of the two lakes in this study was: $\mathrm{ZC}>\mathrm{Zt}>\mathrm{Hc}>\mathrm{Ht}$. . The mean mercury $(\mathrm{Hg})$ concentrations in each fish species of the two lakes were not significantly different at $95 \%(\mathrm{p}=0.05)$ confidence level. Mercury concentration in cat fish species of Ziway Lake was the highest $(0.091 \pm 0.001 \mathrm{mg} / \mathrm{Kg})$ from the rest of species found in the two Lakes and Hawassa tilapia fish was the lowest $(0.078 \pm 0.005 \mathrm{mg} / \mathrm{Kg})$ in mercury concentration. This may be due to territorial nature of the species as well as immobilization of these heavy metals in the lakes. Especially, Ziway Lake has two or more contributory rivers and many chemicals from the vegetable farm land as well as flowering industry found near the town. Then, the Lake can be polluted due to those waste products and it would be directly or indirectly accumulated in the body of the fish.

Mercury is one of the most carcegonic elements found in the earth's crust. Specially, the most notorious compounds are in the forms of compounds such as monomethyl and dimethyl salt of mercury which are soluble in water. They are produced from inorganic mercury in sediment by anaerobic bacteria through the action of methyl-cobalamine and intermediate in the synthesis of methane and get into natural wate [11]. The major anthropogenic sources of mercury are mining, agriculture and industry. There are however new, less explored routes of mercury exposure, such as its presence in cosmetics [12].

\subsubsection{Comparison in Concentration of Each Metal between the Two Lakes}

Heavy metal uptake and accumulation occurs mainly from water, sediments and food [13]. The efficiency of assimilation in different organisms might be affected by many factors such as; ecological needs, feeding habits, habitat, metabolism, biology and physiology of the organisms [14]. Additional environmental factors such as salinity, temperature, season and interacting agents also have impact on this pattern [15].

The concentration of metals in a water sample of the two Lakes was one of the above factors participated in the uptake and accumulation of heavy metals in the body of fish. Lakes also are the home of those fish species. Then, the concentration variation of the two fish species in the two Lakes are discussed as follows:

Table 8. Distribution of trace elements ( $\mathrm{mg}$ elements/L) in water samples of Hawassa and Ziway lakes (mean $\pm S D$ for $n=3$ )

\begin{tabular}{lllll}
\hline \multirow{2}{*}{ No } & \multirow{2}{*}{ Element } & Site & & Detection limit \\
\cline { 3 - 4 } & & $\mathbf{H w}$ & $\mathbf{Z w}$ & \\
\hline 1 & $\mathrm{Cd}$ & $0.066 \pm 0.003$ & $0.06 \pm 0.002$ & 0.014 \\
2 & $\mathrm{Pd}$ & $0.36 \pm 0.03$ & $0.28 \pm 0.01$ & 0.230 \\
3 & $\mathrm{Hg}$ & $0.095 \pm 0.004$ & $0.077 \pm 0.0005$ & 0.056 \\
\hline
\end{tabular}

As shown in the above table the concentrations of $\mathrm{Cd}$ and $\mathrm{Pb}$ have close similarity. The concentration of $\mathrm{Cd}$ and $\mathrm{Pb}$ in the two Lakes was not significantly different. As explained above the concentration of metals in water in the Hawassa Lake was higher than the rest. Therefore, this result shows Hawassa Lake has relatively higher concentration of the heavy metals studied than Hawassa Lake even though industrial as well as domestic discharges get in to the Hawassa Lake more than Ziway Lake. This might be due to many reasons, some of which are:

- the chemical spray of pesticides in vegetable farm land 
near the Lake.

- flowering industry effluents discharging through the river found near Ziway town.

- natural disasters like earthquake, volcanic eruption happening around the lake most of the time [16].

According the students t-test results at $95 \%$ confidence level the mean concentration of heavy metals $\mathrm{Cd}, \mathrm{Pb}, \mathrm{Hg}$ obtained from the water sample of the lakes shown no significant difference between each other.

\subsubsection{Comparison in Heavy Metal Concentration between Fish and the Lakes}

Due to bio-accumulation and bio-magnification of these metals in the body of the fish, the concentration of fish samples was higher than that of the water concentration. Similar results were reported by Glover (1979)[16] and his colleague.

The mean concentration of cadmium, lead and mercury of tilapia as well as cat fish of the two Lakes against the water sample concentration of those heavy metals are not significantly different at $95 \%$ confidence limit according the students t-test shown.

From the results, it can be noted that there may be two factors affecting the element distribution in fish species and lakes:

- Territorial or geographical nature of the lakes,

- Anthropogenic activity around the lake

\section{Conclusions and Recommendation}

The study determined heavy metals concentrations in edible part of two fish species (Oreochromis niloticus and Clarias gariepinus) as well as water sample of Lakes Ziway and Hawassa, Ethiopia, and evaluated bioaccumulation, food chain contamination and ecological hazard level of the toxicants.

The optimum procedure selected for digestion process produced good recovery results ranged from $91.09 \pm 1.3$ up to $104 \pm 1.37$ with RSD below $10 \%$ which shows the efficiency of method used.

In the heavy metal analysis cadmium, lead and mercury were studied. Both $\mathrm{Pb}$ and $\mathrm{Cd}$ concentration in both fish species as well as water samples were not significantly different at $95 \%$ confidence level. However, the concentration of $\mathrm{Hg}$ was significantly different in the water sample of the two lakes but not in the fish species.

Highest concentration $(6.74 \mathrm{mg} / \mathrm{kg})$ of these two lakes obtained from the mercury concentration of Hawassa Lake water and lowest concentration $(0.6 \mathrm{mg} / \mathrm{Kg})$ of those above mentioned metals was obtained from the cadmium concentration of Ziway Lake water.

Although the concentration of mercury was higher than all the international standards that are listed the concentrations of $\mathrm{Pb}$ and $\mathrm{Cd}$ were slightly higher.

The following suggestions are recommended in order to monitor and protect the ecosystem:

- Measurements of residues of heavy metals should be regularly carried out using different fish organs that have the ability to accumulate trace elements such as muscle, bone, liver, gill, kidney, scales, skin, bile, spleen and intestine should be analyzed for each element.

- Environmental concerned organizations which are governmental or nongovernmental such as Ministry of Agriculture, Health and Environmental Protection and others should take due attention on the contamination of the environment and biota with such chemicals.

- Education of the rural farmers about the use of safe pesticides and fertilizers should be encouraged.

- Replacement of chemical use by biological methods for increased crop productivity and pest and vector control should be initiated.

- Continuous and extensive studies on toxicity levels, effects and food chain transfer throughout the country should be carried out to know the burden of toxic chemicals in different areas.

\section{References}

[1] FAO. (1992). Committee for Inland Fisheries of Africa. Report of the third session of The Working Party on Pollution and Fisheries Rome. FAO Fisheries Report. v. 471. P. 43- 44.

[2] EPA, (1994). Feb. Integrated Risk Information SystemCadmium.US Environmental Protection Agency v. 9. p. 74407443.

[3] Glover, J.W., Aust. J., (1979). Concentration of arsenic, selenium and ten heavy metals in school shark Mar. Fresh Water Res V. 30. P. 505-510.

[4] Kaim, W.; Schwedeski, B. John Wiley: Chichester (1994). Bio-inorganic Chemistry; Inorganic Elements in the Chemistry of Life; An Introd. and Guide. V. 8. p. 9-335.

[5] Forstner, U. and Wittmann, G.T. (1983). Springer-Verlag, Berlin. Metal pollution in the aquatic environment. V. 55. P. 162-165.

[6] Gebremariam, Z.; Desta, Z., SINET: (2002). The chemical composition of the effluent from Awassa Textile Factory and its effects on aquatic biota Ethiop. J. Sci. V. 25(2). p. 263-274.

[7] LFDP., (1998). Lake Fisheries Development Project, Fisheries Development in Ethiopia which way now? Project News. Addis Ababa, Ethiopia. Bulletin, v.11. P. 6-8.

[8] Ataro, A.; Wondimu, T.; Chandravanshi, B.S. (2003). SINET: Ethiop. J. Sci., v.103 p.26

[9] Griepink, B. and Tolg, G. (1989). Sample digestion for the determination of elemental traces in matrices of environmental concern. Pure Appl. Chem.v 61. p 1139-1148.

[10] Cohen., T.; Que Hee, S.S.; Ambrose, R.F. (2001) Marine Poll. Bull.,v. 42, p.224-230.

[11] Manahan SE. (1989). Toxicological Chemistry; a guide to toxic substances in chemistry. rooks/Cole Publishing Co, C.A. v.1. pp. 256- 257.

[12] Aranda, P.R.; Gil, R.A.; Moyano, S.; De Vito, I.E.; Martinez, 
L.D. (2008), Cloud point extraction of mercury with PONPE 7.5 prior to its determination in biological samples by ETAAS. Talanta v. 75 , p. 307-311.

[13] Canli, M. and Ay, O. and Kalay, M. (1998). Levels of heavy metal $(\mathrm{Cd}, \mathrm{Pb}, \mathrm{Cu}, \mathrm{Cr}$ and $\mathrm{Ni})$ in tissues of Cyprinus carpio, Barbus capito and Chondrostoma regium from Seyhn river, Turkey. Turk. J. Zool. V.22: p.149-157.

[14] Arellano, J.M., Ortiz, J.B. and Capeta, D.S., Gonzalez, M.L., Sarasquete, C. and Blasco, J. (1999). Levels of copper, zinc, manganese and iron in two fish species from salt marshes of Cadiz Bay (south west Ibrian Peninsula). Biol. Inst. Esp. Oceonogr. v.15:p. 485-488.

[15] Heath, A.G. (1987). CRC press, USA. Wat. Poll. and Fish Physi.p 245-268.

[16] Caroline Le Turdu et. al., (1999) The Ziway-Shala lake basin system, Main Ethiopian Rift: Influence of volcanism, tectonics, and climatic forcing on basin formation and sedimentation Palaeoclima. , Palaeoec. v. 15, p. 135-177 